\title{
Effects of Isoniazid and Its Metabolites on Phenytoin Biotransformation in Isolated Rat Hepatocytes
}

\author{
Hiroshi Noda, ${ }^{*, a}$ Seiji Eto, ${ }^{a}$ Masao Minemoto, ${ }^{a}$ \\ ATSUKO NODA, ${ }^{b}$ and KOHJI OHNO ${ }^{b}$ \\ Department of Hospital Pharmacy, School of Medicine, University of Occupational \\ and Environmental Health, Japan (Sangyo Ika-daigaku), ${ }^{a}$ I-1 Iseigaoka, \\ Yahatanishi-ku, Kitakyushu, 807, Japan, Faculty of Pharmaceutical \\ Sciences, Kyushu University, ${ }^{b}$ 3-1-1 Maidashi, \\ Higashi-ku, Fukuoka 812, Japan
}

(Received June 25, 1986)

\begin{abstract}
The inhibitory effects of isoniazid, its metabolites and related compounds on phenytoin biotransformation were studied in an isolated rat hepatocyte system. Oxidation of phenytoin was inhibited strongly by isoniazid, acetylhydrazine, benzoylhydrazine and phenylhydrazine, and weakly (but significantly) by acetylisoniazid and hydrazine. Isonicotinic acid and diacetylhydrazine showed no effect. These observations may indicate that active hydrazine compounds are ones which can give a relatively significant rise to reactive intermediates such as radicals, diazene compounds or their relatives during the oxidation metabolism. On the other hand, glucuronidation of the oxidized metabolite, 5-phenyl-5-( $p$-hydroxyphenyl)hydantoin, was not affected by isoniazid.
\end{abstract}

Keywords - phenytoin monooxygenation; inhibition; isoniazid; acetylhydrazine; hydrazine; isolated rat hepatocyte; microsomal cytochrome P-450; difference spectrum; spin trapping; glucuronidation

Isoniazid (INH) can inhibit the microsomal mixed function oxidase activity, leading to a reduction of the clearance and an elevation of the plasma level of a co-administered drug. ${ }^{1)}$ In such cases, drug intoxication may develop in patients. The interactions between INH and phenytoin (PHT) have been well studied. The first clinical cases were reported by Murray in 1962; he found that PHT intoxication symptoms developed in approximately $10 \%$ of 630 epileptic patients when they were given INH for the prophylaxis of tuberculosis. ${ }^{2)}$ Later, Kutt et al. $^{3)}$ and Buttar et al. ${ }^{4}$ found that the formation of the pharmacologically inactive oxidation metabolite, 5-phenyl-5-(p-hydroxyphenyl)hydantoin (5-HPPH), was inhibited dose-dependently by co-administration of INH. However, the exact mode of inhibition has still not been fully elucidated, although a spectral investigation of the inhibition on cytochrome P-450 by INH was conducted using rat hepatic microsomes by Muakkassah et al. ${ }^{5)}$ We examined the effect of $\mathrm{INH}$ and some of its metabolic intermediates on the biotransformation of $\mathrm{PHT}^{6)}$ by using isolated rat hepatocytes, which retain the fundamental metabolic functions of the whole liver.

\section{Experimental}

Materials- INH, isonicotinic acid (INA), acetyl hydrazine ( $\mathrm{AcHz}$ ), hydrazine ( $\mathrm{Hz}$ ) sulfate, benzoylhydrazine $(\mathrm{BzHz})$, phenylhydrazine $(\mathrm{PhHz})$ hydrochloride, $\mathrm{PHT}, 5-\mathrm{HPPH}$ and $\alpha$-phenyl-tert-butylnitrone (PBN) were obtained commercially. Acetylisoniazid (AcINH) and diacetylhydrazine (DAcHz) were prepared by the acetylation of INH and $\mathrm{AcHz}$ with acetic anhydride. Collagenase (Clostridium histolyticum) was purchased from Boehringer Mannheim $\mathrm{GmbH}$. Reduced nicotinamide adenine dinucleotide phosphate (NADPH) was obtained from Oriental Yeast Co., Ltd. All chemicals were of reagent grade. 
Preparation and Incubation of Isolated Rat Hepatocytes-- Isolated hepatocytes were prepared from male Wistar rats $(180-220 \mathrm{~g})$ according to the collagenase perfusion method as described by Moldéus et al. ${ }^{7)}$ The viability judged by the lactic dehydrogenase (LDH) latency test ${ }^{8)}$ was $98-99 \%$ for all preparations. Incubation of the hepatocytes was performed at $37{ }^{\circ} \mathrm{C}$ in rotating round-bottomed flasks under a $95 \% \mathrm{O}_{2}-5 \% \mathrm{CO}_{2}$ atmosphere at a cell concentration of $3 \times 10^{6}$ cells/ $\mathrm{ml}$ in a Krebs-Henseleit buffer, $\mathrm{pH} 7.4$, supplemented with $13 \mathrm{~mm}$ HEPES $(N-2$ hydroxyethylpiperazine- $N$-2-ethanesulfonic acid) and $10 \mathrm{~mm}$ glucose. To obtain the time-courses of PHT elimination and 5-HPPH formation in the presence of INH, each substrate was used at $80 \mu \mathrm{M}$. For the examination of the effect on glucuronidation of $37 \mu \mathrm{M} 5-\mathrm{HPPH}, 36.5$ and $73.0 \mu \mathrm{M}$ INH were employed.

Sample Preparations and Assay-After incubation for an appropriate period, $0.1 \mathrm{ml}$ aliquots of the mixture were added to $0.3 \mathrm{ml}$ of acetonitrile solution containing $2 \mu \mathrm{g}$ of phenacetin as an internal standard. 5-HPPH glucuronide was determined as 5-HPPH after heating of the incubation mixture with $3 \mathrm{~N} \mathrm{HCl}$ at $100^{\circ} \mathrm{C}$ for $1 \mathrm{~h}$. PHT and 5-HPPH were assayed by using a Shimadzu LC3-A high-performance liquid chromatograph equipped with a Chemcosorb 3-ODS-H column $(75 \times 4.6 \mathrm{~mm}$ : Chemco Scientific Co.) and a ultraviolet detector (SPD-2A). The mobile phase was a $33: 67(\mathrm{v} / \mathrm{v})$ mixture of acetonitrile- $-0.05 \mathrm{M}$ phosphate buffer $(\mathrm{pH} 6.5)$. The flow rate was $1.0 \mathrm{ml} / \mathrm{min}$ and the eluate was monitored at $210 \mathrm{~nm}$.

Microsomal Cytochrome P-450 Determination_-Microsomes were isolated from livers of male Wistar rats (200-250 g) according to Ernster et al. ${ }^{9)}$ The rats were either untreated or received phenobarbital (three daily i.p. injections of $80 \mathrm{mg} / \mathrm{kg}$ ) prior to sacrifice. Protein content was determined according to the method of Lowry et al. ${ }^{10)}$ and cytochrome P-450 content in rat liver microsomes according to Matsubara et al. ${ }^{11)}$ The effect of $\mathrm{INH}, \mathrm{AcHz}$ or $\mathrm{Hz}$ on cytochrome P-450 was estimated under the conditions described in the legend to Table II.

Spectral Investigation of $\mathbf{A c H z}$ with Rat Liver Microsomal Cytochrome $\mathbf{P}-\mathbf{4 5 0}$ - The difference spectrum of $\mathrm{AcHz}$ with cytochrome P-450 was recorded at room temperature $(20 \pm 2 \mathrm{C})$ on a Shimadzu MPS-2000 spectrometer. The experiment was performed in the reaction mixture described in the legend to Fig. 2 .

Spin Trapping of Acetyl Radical by PBN during Microsomal Metabolism of AcHz-The reaction mixture, containing $5.6 \mathrm{ml}$ of microsomal suspension $(4.4 \mathrm{mg} / \mathrm{ml}), 2.0 \mathrm{ml}$ of $\mathrm{PBN}$ solution $(25 \mathrm{~mm}), 0.2 \mathrm{ml}$ of $\mathrm{AcHz}$ solution $(10 \mathrm{~mm})$ and $0.2 \mathrm{ml}$ of NADPH solution $(1 \mathrm{~mm})$, was incubated at $37^{\circ} \mathrm{C}$ for $20 \mathrm{~min}$, and extracted with benzene. Electron spin resonance (ESR) and mass spectral measurements of the extract were performed by the same method as used for the assignment of hydrazine radical. ${ }^{14}$

\section{Results and Discussion}

The effect of INH on PHT elimination through metabolic oxidation was investigated by using an isolated rat hepatocyte system. The effects of the following compounds were also examined: AcINH, INA, Hz, $\mathrm{AcHz}$ and $\mathrm{DAcHz}$ (metabolites of $\mathrm{INH}$ ), and $\mathrm{BzHz}$ and $\mathrm{PhHz}$ (structurally similar to INH). As shown in Fig. 1-A, INH, $\mathrm{AcHz}, \mathrm{BzHz}$ and $\mathrm{PhHz}$ inhibited PHT elimination strongly, whereas AcINH and $\mathrm{Hz}$ showed a relatively weak (but significant) inhibition. On the other hand INA and $\mathrm{DAcHz}$ did not have any effect on the elimination rate of PHT (Fig. 1-B). The results are consistent with the simultaneous formation of 5-HPPH, during the first 20 min period of incubation (Table I), in that the formation of 5-HPPH was retarded markedly by $\mathrm{INH}$ and $\mathrm{AcHz}$, almost completely by $\mathrm{BzHz}$ and $\mathrm{PhHz}$, and slightly but significantly by AcINH and Hz. The rate of 5-HPPH formation was not affected by INA or $\mathrm{DAcHz}$, as expected.

The main course of PHT metabolism is known to be oxidation followed by glucuronidation. ${ }^{12)}$ Muakkassah et al. investigated the mechanism of the inhibitory action of INH on microsomal drug metabolism. ${ }^{5}$ They found that the addition of INH to rat liver microsomes
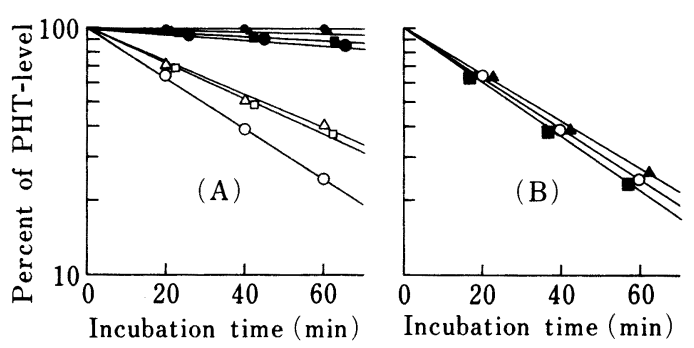

Fig. 1. Effects of INH-Related Compounds on PHT Elimination in Isolated Rat Hepatocytes $\left(80 \mu \mathrm{M} / 3 \times 10^{6}\right.$ cells $\left./ \mathrm{ml}\right)$

(A): O, control; $\mathbf{\square}, \mathrm{INH} ; \bullet, \mathrm{PhHz} ; \boldsymbol{\Delta}, \mathrm{BzHz} ; \bullet$, AcHz; $\triangle, \mathrm{Hz} ; \square$, AcINH. (B): $\mathrm{O}$, control; $\Delta$, $\mathrm{DAcHz} ; \boldsymbol{\square}$, INA. 
TABLE I. Effects of INH and Related Compounds on 5-HPPH Formation

\begin{tabular}{lrcc}
\hline $\begin{array}{c}\text { INH and related } \\
\text { compounds }\end{array}$ & 5-HPPH formation ${ }^{a)}$ & $\begin{array}{c}\text { Inhibition } \\
(\%)\end{array}$ & $\begin{array}{c}\text { Statistical } \\
\text { significance }\end{array}$ \\
\hline Control & $31.7 \pm 0.4$ & 0.0 & - \\
INH & $4.7 \pm 0.3$ & 85.1 & $p<0.001$ \\
$\mathrm{PhHz}$ & $0.8 \pm 0.1$ & 97.5 & $p<0.001$ \\
$\mathrm{BzHz}$ & $2.2 \pm 0.4$ & 93.2 & $p<0.001$ \\
$\mathrm{AcHz}$ & $6.7 \pm 0.7$ & 79.0 & $p<0.001$ \\
$\mathrm{~Hz}$ & $26.6 \pm 1.1$ & 16.3 & $p<0.02$ \\
$\mathrm{AcINH}$ & $28.6 \pm 1.7$ & 10.0 & $p<0.05$ \\
INA & $31.3 \pm 1.1$ & 1.2 & $\mathrm{NS}$ \\
$\mathrm{DAcHz}$ & $30.1 \pm 1.6$ & 5.2 & $\mathrm{NS}$ \\
\hline
\end{tabular}

Each initial substrate concentration was $80 \mu \mathrm{M}$. Each value represents the mean \pm S.D. of three experiments. Results were compared by means of Student's $t$-test. a) $\mu \mathrm{M} / 3 \times 10^{6} \mathrm{cells} / \mathrm{ml} / 20 \mathrm{~min}$. NS: Not significant.

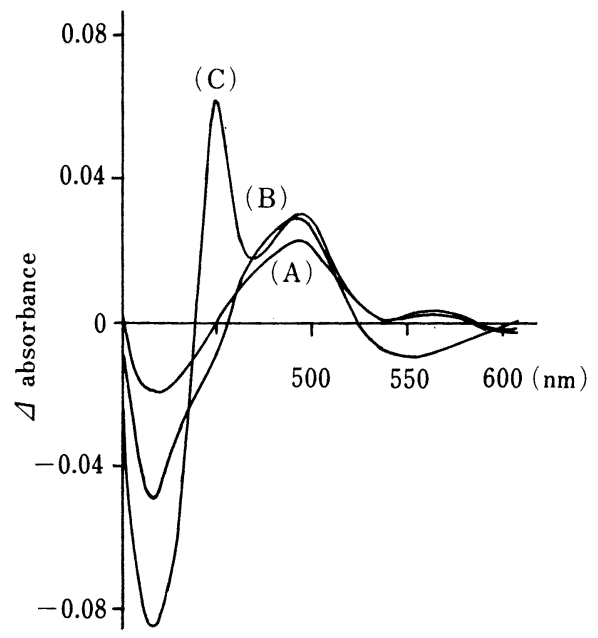

Fig. 2. Difference Spectra Produced by Interaction of $\mathrm{AcHz}$ with Cytochrome P-450

Rat liver microsomes were suspended in potassium phosphate buffer solution ( $\mathrm{pH} 7.4)$, and $5.6 \mathrm{ml}$ of the suspension $(4.4 \mathrm{mg} / \mathrm{ml})$ was divided into two cuvettes. After recording a flat base-line, $0.1 \mathrm{ml}$ of $\mathrm{AcHz}$ solution was added at a concentration of $0.1 \mathrm{~mm}$ to the sample cuvette and an equal volume of buffer was added to the reference cuvette. The tracings A, B and $C$ represent the difference spectra recorded 2,4 and $6 \mathrm{~min}$ after the addition of NADPH solution $(1.0 \mathrm{~mm})$ to both cuvettes.

(A), 2 min; (B), 4 min; (C), 6 min.

produced an immediate decrease in the binding of carbon monoxide to reduced cytochrome P-450, which could contribute to the inhibition of the mixed function oxidase system by INH. Nicotinic acid hydrazide and $\mathrm{BzHz}$ had the same effect, whereas $\mathrm{AcHz}$ was inactive. From these findings, they suggested that the hydrazine moiety $\left(-\mathrm{NHNH}_{2}\right)$ bearing an aroyl group is a dominant functional group in the inhibition of cytochrome P-450. Our results also indicate that the free hydrazine terminal is an essential functional group for the inhibition of PHT monooxygenation. However, the presence of an aroyl group is not essential. The oxidation of PHT was inhibited almost completely by $\mathrm{PhHz}$, strongly by $\mathrm{AcHz}$ and weakly (but significantly) by $\mathrm{Hz}$ itself, and these are not aroyl compounds (Fig. 1-A, Table I). It was reported that the oxidation of $\mathrm{PhHz}$ with microsomal cytochrome $\mathrm{P}-450$ gave phenyl diazene through the formation of a radical intermediate. ${ }^{13)}$ Our group has also found that $\mathrm{Hz}$ is oxidized via the successive formation of hydrazine radical $\left(\mathrm{H}_{2} \mathrm{NNH}\right)$ and diimide $(\mathrm{NH}=\mathrm{NH})$ during incubation in rat liver microsomal suspensions, as well as in isolated rat hepatocytes. ${ }^{14)}$ In addition, it was found that $\mathrm{Hz}$ produces an NADPH-dependent difference spectrum characterized by a maximum at $448 \mathrm{~nm}$, which can be inhibited by metyrapone. This suggested the formation of a complex of diimide and rat liver cytochrome P-450.

As for the interaction of $\mathrm{AcHz}$ with rat liver cytochrome P-450, Muakkassah et al. 
TABle II. Effects of INH, $\mathrm{AcHz}$ and $\mathrm{Hz}$ on Cytochrome P-450 Contents in Rat Liver Microsomes

\begin{tabular}{cccc}
\hline \hline \multirow{2}{*}{$\begin{array}{c}\text { Substrate } \\
\text { concentration } \\
(\mathrm{mM})\end{array}$} & $\mathrm{3NH}$ & $\mathrm{C}$ & $\mathrm{AcHz}$ \\
\cline { 2 - 4 } & 100 & 100 & $\mathrm{~Hz}$ \\
\hline 0 & $87.9 \pm 1.7^{a)}$ & $92.3 \pm 1.2^{b)}$ & 100 \\
0.5 & $85.6 \pm 1.7^{a)}$ & $89.0 \pm 2.9^{b)}$ & $86.4 \pm 0.8^{a)}$ \\
1.0 & & & $85.6 \pm 1.6^{a)}$ \\
\hline
\end{tabular}

The reaction mixture, containing $2.8 \mathrm{ml}$ of microsomal suspension $(3.5 \mathrm{mg} / \mathrm{ml}), 0.2 \mathrm{ml}$ of the substrate solution and $1.0 \mathrm{ml}$ of NADPH solution $\left(1.0 \mathrm{~mm}\right.$ ), was incubated at $37^{\circ} \mathrm{C}$ for $10 \mathrm{~min}$, and the cytochrome P450 contents were measured according to Matsubara et al. ${ }^{11)}$ The control value of $1.67 \pm 0.03 \mathrm{nmol} / \mathrm{mg}$ protein is expressed as $100 \%$. Each value represents the mean \pm S.E. of $3-5$ experiments. a) $p<0.01, b) p<0.05$.

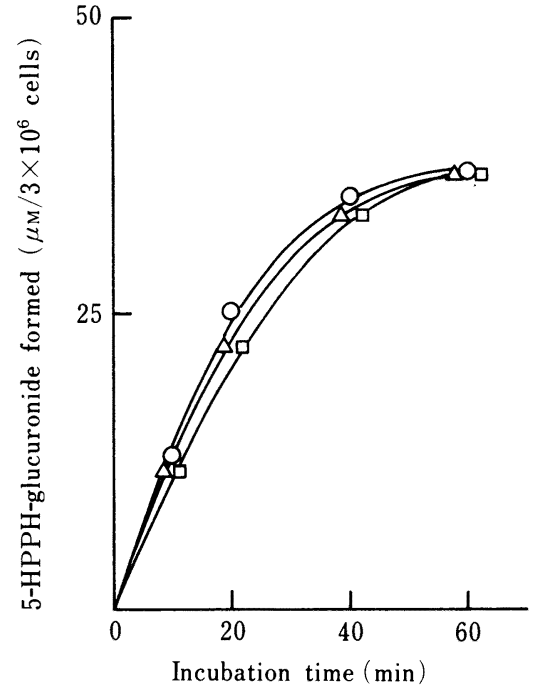

Fig. 3. Effect of INH on 5-HPPH Glucuronidation in Isolated Rat Hepatocytes

Initial concentration of 5-HPPH: $37 \mu \mathrm{M}$. $\bigcirc$, control; $\triangle, 36.5 \mu \mathrm{M}$ INH; $\square, 73.0 \mu \mathrm{M}$ INH.

reported that $\mathrm{AcHz}$ was inactive towards cytochrome $\mathrm{P}-450 .{ }^{5)}$ However, $\mathrm{AcHz}$ gave a fairly stable NADPH-dependent difference spectrum characterized by maxima at $451 \mathrm{~nm}$ (sharp) and $495 \mathrm{~nm}$ (broad), as shown in Fig. 2. Pretreatment of the microsomes with metyrapone $(0.02 \mathrm{M})$ decreased $\Delta A_{451-540}$ to $36.9 \%$ and $\Delta A_{495-540}$ to $89.0 \%$ of each control value. Pretreatment with PBN (5.0 mM) instead of metyrapone lowered $\Delta A_{451-540}$ to $86.3 \%$ and $\Delta A_{495-540}$ to $58.9 \%$ of the control values, respectively. It may be concluded that the peak at $451 \mathrm{~nm}$ arises from the cytochrome P-450 complex with a diazene-type metabolite $(\mathrm{RN}=\mathrm{NH})$, and the absorption at $495 \mathrm{~nm}$ is due to acetyl radical $\left(\mathrm{CH}_{3} \mathrm{CO}\right)$. Acetyl radical formation is also supported by the fact that the mass spectrum of the benzene extract of the microsomal oxidation mixture of $\mathrm{AcHz}$ in the presence of a spin trapping agent, $\mathrm{PBN}$, clearly showed the formation of the corresponding PBN-adduct $(m / z 220)$. Furthermore, as shown in Table II, cytochrome $\mathrm{P}-450$ contents in the microsomal suspensions were significantly decreased by the addition of $\mathrm{AcHz}, \mathrm{Hz}$ or $\mathrm{INH}$. These results argue against the conclusion of Muakkassah et al. concerning the inactivity of $\mathrm{AcHz}$ towards cytochrome $\mathrm{P}-450{ }^{5}$ )

These observations may imply that active hydrazine compounds are the ones which can give a relatively significant rise to reactive intermediates such as radicals, diazene derivatives, or their relatives, which probably participate in the inhibitory effect on the mixed function oxidase systems responsible for PHT oxidation. AcINH can be hydrolyzed metabolically to 
afford active $\mathrm{AcHz}$ and inert INA, ${ }^{6)}$ which could explain the relatively weak inhibitory effect of AcINH.

Buttar investigated the biliary excretion of PHT and its metabolites in rats, and suggested that administration of INH inhibited the glucuronidation of 5-HPPH as well as the $p$ hydroxylation of PHT $^{4 a}{ }^{4}$ Isolated hepatocytes, which retain a variety of fundamental metabolic functions including glucuronidation, were used to elucidate whether PHT intoxication is related to the inhibition of 5-HPPH glucuronidation by INH, which may result in the induction of a negative feedback on the formation of 5-HPPH. ${ }^{15)} \mathrm{INH}$, however, had no effect on the conjugation (Fig. 3).

The results mentioned above probably indicate that the delay in PHT elimination was predominantly due to the inhibition of the monooxygenation of PHT by INH and its active metabolites possessing a free hydrazine terminal or their biotransformed active ones. Further investigations are in progress.

Acknowledgement The authors are grateful to Dr. M. Hirata, Shionogi Research Laboratories, Shionogi and Company, Ltd., for his helpful comments on the experiments.

\section{References}

1) V. C. Valsalan and G. L. Cooper, Brit. Med. J., 285, 261 (1982); G. Sutton and H. J. Kupferberg, Neurology, 25, 1179 (1975); A. R. Rosenthal, T. H. Self, O. E. Baker and R. A. Linden, J. Am. Med. Assoc., 238, 2177 (1977); H. R. Ochs, D. J. Greenblatt, G. M. Roberts and H. J. Dengler, Clin. Pharmacol. Ther., 29, 671 (1981); R. R. Millar, J. Porter and D. J. Greenblatt, Chest, 75, 356 (1979); D. R. Witmer and W. A. Ritdchel, Drug Intell. Clin. Pharm., 18, 483 (1984).

2) F. J. Murray, Am. Rev. Resp. Dis., 86, 729 (1962).

3) H. Kutt, K. Verebely and F. McCowell, Neurology, 18, 706 (1968); H. Kutt, R. Brennan, H. Dehejia and K. Verebely, Am. Rev. Resp. Dis., 101, 377 (1970).

4) a) H. S. Buttar, Res. Commun. Chem. Pathol. Pharmacol., 18, 35 (1977); b) H. S. Buttar, L. T. Wong and J. H. Moffatt, Arch. Int. Pharmacodyn. Ther., 235, 9 (1978).

5) S. F. Muakkassah, W. R. Bidlack and C. T. Yang, Biochem. Pharmacol., 30, 1651 (1981).

6) W. W. Weber and D. W. Hein, Clin. Pharmacokin., 4, 401 (1979) and references cited therein.

7) P. Moldéus, J. Horberg and S. Orrenius, Methods in Enzymol., 52, 60 (1978).

8) J. Högberg and A. Kristoferson, Eur. J. Biochem., 71, 77 (1977); D. Köster-Albrecht, H. Kappus and H. Remmer, Toxicol. Appl. Pharmacol., 46, 499 (1978).

9) L. Ernster, P. Siebivity and G. Palade, J. Cell Biol., 15, 541 (1962).

10) O. H. Lowry, N. J. Rosebrough, A. L. Farr and R. J. Randall, J. Biol. Chem., 193, 265 (1951).

11) T. Matsubara, M. Koike, A. Touchi, Y. Tochino and K. Sugeno, Anal. Biochem., 75, 596 (1976).

12) N. Gerber, W. L. Weller, R. Lynn, R. E. Rangno, B. J. Sweetman and M. T. Bush, J. Pharmacol. Exp. Ther., 178, 567 (1971); T. Inaba and T. Umeda, Drug. Metab. Dispos., 3, 69 (1975).

13) H. G. Jonen, J. Werringloer, R. A. Prough and R. W. Estabrook, J. Biol. Chem., 257, 4404 (1982).

14) A. Noda, H. Noda, K. Ohno, T. Sendo, A. Misaka, Y. Kanazawa, R. Isobe and M. Hirata, Biochem. Biophys. Res. Commun., 133, 1086 (1986).

15) P. Borondy, T. Chang and A. J. Glazko, Pharmacologist, 31, 582 (1972). 